\title{
The Justice of God in his Anger: A Narrative Analysis of Isaiah 5:1-7 and its Implications for Socio-Economic and Security Challenges in Nigeria*
}

\author{
SAMSON O. Olanisebe (OBAFEMI Awolowo University, Nigeria)
}

\begin{abstract}
The passage of Isa 5:1-7 could be regarded as a dirge about the unfruitfulness and wastefulness of God's resources by the people of Judah. The people were provided with every resource needed to blossom in their endeavours, they were given the enabling environment and favourable weather, but when the time of harvest came, instead of bringing forth good fruit and bountiful harvest, they brought forth wild grape. The output does not justify the input. The owner of the resources was angered by this situation and took up a complaint against the people and decided to punish them severely. This situation of Judah is not dissimilar with that of Nigeria, who is presently experiencing endemic poverty, insecurity, corruption and political instability in the midst of abundance of minerals, human and material resources. The aim of this article is to carry out a narrative analysis of Isa 5:1-7, looking at the complaint of Yahweh against the people of Judah and contextualize the results of the exegesis, with the aid of intercultural hermeneutics, to the Nigerian situation, whose current socio-economic and political experience is not different from that of Judah.
\end{abstract}

Keywords: God, Justice, Parable of the Vineyard, Insecurity and Nigeria.

\section{A INTRODUCTION}

The book of Isaiah is one of the prophetical books of the OT corpus. The book has been classified by the Hebrews as belonging to the Latter Prophets. The book and prophesy of Isaiah are very significant. It opens the books of the latter prophets and the first of the three Major Prophets of the OT. Its significance accrues from the national situations, which formed the background to the prophecies of the book. According to John Bright, ${ }^{1}$ "the books of the Prophets of the eight century in Judah which ceaselessly addressed themselves to the

* To cite: Samson O. Olanisebe, "The Justice of God in his Anger: A Narrative Analysis of Isaiah 5:1-7 and its Implications for Socio-Economic and Security Challenges in Nigeria," OTE 28, no. 2 (2015): 481-496. DOI: http:// dx.doi.org /10.17159/2312-3621/2015/v28n2a14

1 John Bright, A History of Israel (3rd ed.; London: SCM Press, 1982), 288. 
national emergency must not be overlooked. To do so, according to him, would be to leave history incomplete, for these Prophets were certainly of far greater historical significance than any of Judah's Kings or Assyria's for that matter." The prophecies of Isaiah, looking at the periods of the three kings mentioned in connection with the period of his call and mission, came during a period of national crisis in Judah in which an enemy was harassing the Judeans. ${ }^{2}$ First was the external and physical threat from the Assyrians. Coupled with this was the anti-Assyrian alliance by the kings of Syria and Israel into which they wanted to co-opt Ahaz king of Judah. Failure of Ahaz to give Judean support would amount to his deposition and enthronement of a puppet king that would cooperate with the anti-Assyrian alliance.

Apart from the external crisis, there was a spiritual emergency, which threatened the national character and the national religion of Judah. The cause of this crisis must be traced to both the spiritual and social sins (corruption) being committed by Yahweh's elected people. There were social and economic inequalities among the people based on extortion and concentration of the national wealth in the hands of the few, and for which the official religion had no effective means of checkmating. According to Barry Webb in his book The Message of Isaiah, ". . . the new found wealth was not evenly distributed. It was concentrated in the hands of the economic elites who cared little for the have-nots beneath them. Deep fissures were opening up in the Judean society as justice was bought and sold, or simply disregarded and replaced by violent exploitation and repression. Religious observance continued but could no longer conceal the rot that had set in underneath." "In addition, there was the relapse into idolatry and religious syncretism practiced by the people especially in the lax days following Ahaz's recognition of the Assyrian gods. At this period, the cult officials, whose responsibilities were to caution the kings and ensure proper worship of Yahweh, became silenced, because they entertained the false beliefs that the state could not fall as a result of Yahweh's firm covenant with the Davidic dynasty. ${ }^{4}$ It is against this background that this paper examines one of the messages of the prophet Isaiah against the chosen people of Yahweh in Isa 5:1-7 and contextualizes the outcome of the study into the Nigerian situation with the aid of intercultural hermeneutics.

\section{B THE STRUCTURE AND SOCIO-HISTORICAL CONTEXT OF ISAIAH CHAPTER 5}

Traditionally the book of Isaiah is divided into three main sections namely Proto-Isaiah, which B. S. Childs describes as the pre-exilic prophet of judgment, Deutero-Isaiah (the exilic prophet of consolation) and Trito-Isaiah (the

2 Charles F. Whitley, "The Call and Mission of Isaiah,” JNES 18/1 (1959): 38.

3 Barry Webb, The Message of Isaiah (Leicester: Inter-Varsity Press, 1996), 22.

4 Bright, History of Israel, 289. 
post exilic prophet of promise). ${ }^{5}$ The chapterization of the tripartite division includes 1-39 for Proto Isaiah, 40-54 for Deutero-Isaiah and 55-65 for TritoIsaiah. However, scholars like W. H. Brownlee and C. C. Torrey have canvassed for two main division of the book of Isaiah (chs. 1-33 and 34-66). To Brownlee, this division is necessary because of the observation that the Qumran scribe used one scroll of Isaiah to copy chs. 1-33 and another scroll to copy 34-66 and the parallelism and balance observed in the two halves. ${ }^{6}$ However, both Childs and Brownlee agree on the unity of the canonized text of Isaiah and that the editor of the book of Isaiah has carefully excised the historical contexts of the second and third Isaiah and placed the oracles into the historical context of the 8th century prophet in order to forge the aforementioned theological unity. In the process, the editor has rearranged the oracles, placing oracles from the first into the second and vice-versa, thus creating timeless theological themes of rejection and remnant, judgment and redemption. ${ }^{7}$ It is instructive to note that Isa 5, which is the focus of this paper, falls within the purview of proto-Isaiah, which x-rays the strain relationships between the Southern Kingdom and Yahweh, the former always going against the covenantal stipulations of the latter, resulting into oracles of judgment against the people of God. Looking at the context of Proto-Isaiah, Sheppard believes that the judgment and justice of Yahweh is most appropriate because the same irrevocable judgment of Yahweh that Isaiah announced to the Northern Kingdom, was redactionally reapplied to the Southern Kingdom, thereby the demands of divine justice are now extended to "the whole earth" and to "all the nations" in the judgment oracles against other gentile nations. These woe or judgment oracles are further reinforced by the refrain, "For all this, his anger is not turned away and his hand is stretched out still" $(5: 25 \mathrm{~b} ; 9: 11 \mathrm{~b}, 16 \mathrm{~b}, 20 \mathrm{~b}){ }^{8}$

As regards the genre to which the message of Isa 5:1-7 belongs, Willis has been able to trace various scholars' views. For instance, Jerome, Luther and Ewald have considered it as an Uncle's song; Graham has seen it as a satirical polemic against Palestinian fertility cults; Gray suggests that it is the Prophet's song concerning his own vineyard; Cersoy sees it as the Prophet's song expressing sympathy for his friend Yahweh; Cheyne suggests that it might be a drinking song usually sung by the drunkard; Schmidt believes it is a bride's love song; Bentzen says that it a lament or complaint of a disappointed lover; Jonker sees it as a song of the friend of the bridegroom; Fohrer believes it is a lawsuit or accusation; Weiser, Eissfeldt and Schottroff are of the opinion that it is fable; Young, Wildberger, Ruffenach and Bentzen believe it is allegory and

5 Craig A. Evans, "On the Unity and Parallel Structure of Isaiah,” VT 38/2 (1988): 129.

6 Evans, "On the Unity," 132.

7 Evans, "On the Unity," 129.

8 Gerald T. Sheppard, "The Anti-Assyrian Redaction and the Canonical Context of Isaiah 1-39," JBL 104/2 (1985): 195. 
some other scholars believe that it is parable. Willis, while respecting the opinions of various scholars, however punctured many of the reasons put forward and suggested that the song could be regarded as a parable. Then he proposes that based on a number of factors which he puts forward, among which is the single lesson which a parable usually contains, the similarities between Yahweh and husbandman, Israel and vineyard, were appropriate and natural, not fanciful and inappropriate, as in the allegory, to the ancient mind, and that one can have a combination of lawsuit and song in a parable, which are all applicable to Isa 5:1-7. ${ }^{9}$ However, the present paper considers the text as a parable with the intention to teach a lesson on the relationship between Yahweh and the people of Judah.

It should be noted that the socio-historical setting or context of Isa 5 cannot be divorced from the context of the call of the prophet Isaiah himself. The reason is that the chapter in question falls within the first six chapters that housed the call of Isaiah. The opening verse of Isa 1:1 hinted that the prophet's call and mission fell within the reign of four kings of Judah, namely Uzziah, Jotham, Ahaz and Hezekiah. While the dating of Isa 1-6 is difficult to ascertain, scholars however, agree that ch. 7 could be dated to ca. 733 B.C.E. because it was during this time that Syria and Samaria invaded Judah which caused Ahaz to ask Assyria for help. This information can then help to date chs. 1-6, since ch. 6 is dated seven years earlier, therefore, most, if not all, of chs 1-6 can be dated around 745-740 B.C.E., or in other words, a few years before the death of Uzziah.

Scanning through the contents of the introductory chapters of Isaiah, one can garner that that the socio-historical context of Isa 5 was a time of great wickedness toward Yahweh's covenant, which is indicated by the people's idolatrous way of life by worshipping their pagan neighbours' gods (chs. 1-4), and which eventually culminated in Yahweh's pronouncement of judgment on the rebellious people (ch. 5). In addition, since Isaiah's official commission is located in the year that king Uzziah died, the socio-historical context of Isa 5 cannot be inextricably tied to the prevailing socio-economic and political condition of Judah during the reign of Uzziah. Uzziah ruled effectively from ca. 783-742 B.C.E.. He helped Judah attain economic and military success at a time when Jeroboam II enjoyed an even greater reign in Samaria. Despite this prosperous times, Yahweh was not pleased with the people. Hosea and Amos who ministered during the earlier decades of the eras of Uzziah and Jeroboam, charged the people and their rulers with variety of individual and societal sins. By the time Uzziah died, the people were ripe for judgment. ${ }^{10}$ In spite of the material prosperity enjoyed by Judah during this period and which should have

9 John T. Willis, “The Genre of Isaiah 5:1-7," JBL 9/3 (1977): 337-338.

10 Paul R. House, "Isaiah's Call and Its Context in Isaiah 1-6," CTR 6/2 (1993): 209211. 
served as a means of drawing the people to Yahweh, the people engaged in the violation of Yahweh's covenant. Also, the leaders of the nation who formerly had been pure and valuable, were now adulterated and cheap. Rather than serving the people, they served themselves. Idolatry had led to social injustice. ${ }^{11}$ As a matter of fact, Chaney painted vividly the economic life of the 8 th century Israel by observing that Israel and Judah experienced an increase in international trade that made their leaders import luxury goods, military material and materials for monumental architectural buildings. In order to pay for these imported materials, food-stuffs, particularly the triad of wheat, olive oil, and wine, were exported. These imports mostly benefited an elite minority, while the exports necessary to procure them, cut deeply into the sustenance of the peasant majority. ${ }^{12}$

In view of the fact that the period of Isaiah's prophecy coincided with the period when Amos also prophesied in northern Israel, the socio-historical context of Isaiah could not be that much dissimilar to that of Amos. Amos' message occurred during the reign of Jeroboam II. This period in Israel had been described as "The Victorian Age." It was a time of prosperity and a renewed national confidence. The official religion was growing and festivals were popular, but the old social order had disintegrated as there was a wide gap between the arrogant luxury of the rich and the misery of the poor, a condition that made the old Israelite ideal of brotherhood seem an anachronism. ${ }^{13}$ This similarity in the socio-historical backgrounds of both southern and northern Israel at this period, is very crucial as it will shed more light on the prophet's identification of the vineyard in the parable to be both men of Judah and house of Israel.

\section{NARRATIVE ANALYSIS OF ISAIAH 5:1-7}

The author of Isa 5 decided to pass his message across to the people through a

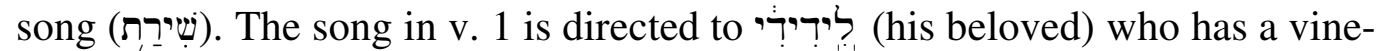
yard. The noun dod that is translated "beloved," is translated by Jerome as "my (paternal) cousin" and by Aquila and Ewald as "my (paternal) uncle." According to Willis, while it is true that dod means "paternal uncle" in a number of passages (cf. Lev 10:4; 20:20; 25:49; Num 36:11; 1 Sam 10:14, 15, 16; 14:50; 2 Kgs 24:17; Amos 6:10; Jer 32:7, 8, 9, 12; 1 Chr 27:32; Esth 2:7, 15), it also means "beloved, darling, friend," in many passages in Canticles $(1: 13,14,16$; $2: 3,8,9,10,16,17 ; 4: 16 ; 5: 2,4,5,6,8,9,10,16 ; 6: 1,2,3 ; 7: 10,11,12,14$, etc.), where it is found exclusively on the lips of young maiden speaking about

11 Thomas L. Constable, "Notes on Isaiah," (2015 Edition), pp. 5, 21 [cited 22 June 2015]. Online: http://soniclight.com/constable/notes/pdf/isaiah.pdf.

12 Marvin L. Chaney, "Whose Sour Grapes? The Addressees of Isaiah 5:1-7 in the Light of Political Economy," SEMEIA 87 (1999): 107.

13 George W. Anderson, A Critical Introduction to the Old Testament (London: Gerald Duckworth \& Co. Ltd., 1974), 148. 
or to the young man she loves, and this is the more natural meaning it acquires in Isa $5: 1 .^{14}$ The location of the vineyard is described as "a horn son of oil" which is a Hebrew idiomatic expression for a fertile hill. What readily comes to mind with the opening of $\mathrm{v} .1$ is that the song describes the relationship between the friend of the author and his vineyard. Some scholars like G. R. Williams, however, believes that the vineyard of the poet's friend is not to be understood literally but as a figure for female lover. ${ }^{15}$ In other words, one may deduce that the song is about the marital relationship about the friend of the poet and the wife of the former. This position is plausible because in the OT and in ANE literature, the vineyard, the garden and the field are used to describe erotic sexual relationship between two lovers. ${ }^{16}$

The efforts of the owner of the vineyard are described in v. 2 where he digs round the vineyard and builds a fence or wall around it, clearing the land of stone. Probably this does not mean all stones but mainly those that would hinder the development of healthy vines, and even planted שירק (choice species of vine). The presence of וג "and even" preceding the wine press in v. 2 draws attention to the fact that a vineyard does not need not have a wine press. But that the owner provided it, indicates higher expectations of the vine grapes to be pressed. This, to Williams, suggests the kind of care that the husband provided for the wife, which is expected of every responsible husband. Furthermore it also suggests that the expectation of grapes, a symbol of children in $\mathrm{v}$. $2 c$, is justified, and that the final word of the verse ביבאשים (stinking grapes) perhaps representing illegitimate children, comes as a surprise. ${ }^{17}$ Having planted the vineyard and after doing everything that was necessary for it to produce fruit, the owner of the vineyard, in anticipation of the bountiful harvest, prepared also the place where he would store the produce. This is what W. C. Graham has called the motif of expected fruit. ${ }^{18}$

Verse 3 is an appeal from the owner of the vineyard calling on the יוֹשישב: (dwellers of Jerusalem) to judge between him and his vineyard. Here the owner of the vineyard is appealing to the conscience of the people in general to consider his efforts on the vineyard and the produce that came out of it and to determine who has erred between him and the vineyard. He puts the questions to the people in v. 4 and asks them what they thought he could have done (in addition to all that he did for the vineyard in v. 2). Was there anything that he left undone? Why did he seek for grapes from it and it brought stinking

14 Willis, "The Genre," 337-338.

15 Gary R. Williams, "Frustrated Expectations in Isaiah V 1-7: A Literary Interpretation," VT 35/4 (1985): 460.

16 Willis, "The Genre," 345.

17 Williams, "Frustrated Expectations," 460-461.

18 William C. Graham, "Notes on the Interpretation of Isaiah 5:1-14," AJSL 4/3 (1929): 170. 
fruit? These questions are necessary, because if the fault is with the owner of the vineyard, he would then know that the poor yield was as a result of his error of omission and the vineyard will be absolved from the frustrated expectation of its owner. These questions further reveal the extent of the frustration experienced by the owner. He was pained to the marrow that in spite of all his efforts on the vineyard for a fruitful and bountiful harvest, all his labour was wasted and all it produced were stinking fruits.

However, the owner of the vineyard was not patient enough to listen to the answers and the verdict of the people to whom he has directed his questions before he meted out his own punishment to the vineyard in v. 5. As a result of the frustration, the owner of the vineyard took a decision about what he was going to do with the vineyard. Firstly, he would remove the משוּרָּתו (his hedge) around it. Secondly, he would allow it to be burned to break away the (his

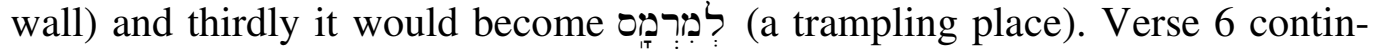
ues with the punishment that the vineyard would be destroyed and there would be no song heard in it, it would not be hoed or cultivated so that only thorns and thorn bushes would continue to grow up in it and the rain would be commanded not to rain upon it. This judgment possibly signifies the exile that the tribe of Judah would eventually be sent into, making their land to become desolate which was regarded as the land having its Sabbath rest. This punishment to the vineyard might have arisen out of anger, but the question could be asked if the action of the owner of the vineyard cannot be justified?

In v. 7, there is a twist of events as the prophet decided to reveal the true meaning of the parable. Prior to this point, the people who have been asked to judge the situation were likely to have been heaping blame on the vineyard and condemning it for its unproductive nature and wastefulness of abundant resources invested on it. However, the prophet declares that the owner of the vineyard is not actually the friend of the poet but יהוֹ: (Yahweh) and that the

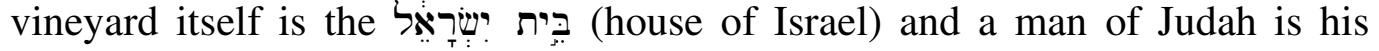
delightful plantation. As regards the identification of the vineyard to be the

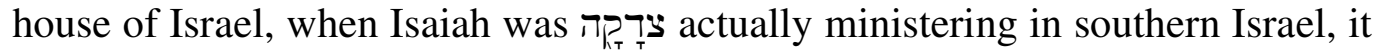
is important to note that before the fall of Samaria in 722 B.C.E. "the house of Israel" meant either the whole divided nation or its northern component. The prophets did not countenance the division, and whether they were specifically called to prophesy to the north or the south, they tended to embrace the whole Israel in their ministry (cf. Amos 3:1). Isaiah thus addressed the whole nation and then narrowed his vision to the specifically privileged men of Judah. ${ }^{19}$

When Yahweh looked for justice among his people, what he got in return was blood and when he looked for righteousness, he got an outcry. The

19 J. Alec Motyer, The Prophecy of Isaiah: An Introduction and Commentary (Downers Grove: Inter Varsity Press, 1993), 69. 
צִדקָה (righteousness) in v. 7 has been variously interpreted as a saving act, especially when it is predicated of God, but it can also mean the punitive righteousness of Yahweh when used in connection with the doxologies of judgment. ${ }^{20}$ It has been observed also that there is a fundamental difference in the sense in which the two words (justice) and (righteousness) are used in the two or three divisions of the book of Isaiah. In the first part, in which our passage of exegesis falls, the two words, when joined together with the Hebrew waw (and), are always used in relation to human behaviour, that is, how they can create and preserve righteousness and justice or their neglect, and in the second part of Isaiah, they are always used in relation to God's acts or behaviour. When Yahweh therefore says in v. 7 that he looks for justice but found bloodshed and he looks for righteousness but found an outcry, he is referring to the perversion and the absence of justice and righteousness that are to characterize the behaviour of his chosen people. Whether the justice and righteousness in question refer to divine or human, the implication is that both spheres (sacred and secular) are to exhibit the two interrelated moral qualities in their day-to-day relationships and endeavours. However, in most cases, it seems that the humans are always falling short of exhibiting these moral qualities. This warranted the intervention of the sacred acting as a check to them through the threat of punishment. The threat included the removal of hedge and fences around the wall, not allowing the vineyard to be hoed, refusal to allow rain to fall on it and allowing it to become a trampling place, which are metaphors of economic loss and removal of protection or security.

Ordinarily one will think that the vineyard should typify the land or the geographical locale on which the nation of Israel is planted, but v. 7, which has been regarded as the interpretation of the parable by the author equates the vineyard with the house of Israel, pointing to the fact that Yahweh is interested in Israel, the social group, rather than in the natural environment in which they dwell. Yahweh's prime concern is the fruit of human relationships, the fruit of the moral aspect of life, rather than the fruit of soil. ${ }^{21}$ In the light of v. 7, the vineyard is Israel and the prophet's well beloved is Yahweh. The fruitful hill is the fertile land of Canaan. That Israel was the beloved vine, plant, or vineyard of Yahweh, and that Yahweh had driven out the Canaanites to transplant his beloved nation were popular images called up by other prophets like Hosea, Jeremiah and Ezekiel. ${ }^{22}$

20 R. Walter L. Moberly, "Whose Justice? Whose Righteousness? The Interpretation of Isaiah V 16," VT 51/1 (2001): 60.

21 Graham, "Notes," 171.

22 Kwok Chi Keung, "An Analysis of the 2 Vineyard Songs in Isaiah" (Graduation Thesis, Hong Kong Catholic Biblical Institute, 2007), 22. 


\section{SUMMARY FROM THE ISAIAH'S SONG OF THE VINEYARD}

Looking generally at the song of the vineyard discussed above, one discovers that the breadth of emotions stretches between a love song at the beginning to a knell at the end. The song quickly becomes sour as it compares the expectation with the result. ${ }^{23}$ Also it is discovered that the song has the setting of a court room in which the plaintiff or complainant brought a law suit against the offender before the judge, and demands that justice be done between him and the accused. In other words, the song has the form of juridical parable. ${ }^{24}$ In the song, the plaintiff is Yahweh, through the instrumentality of his prophet, the accused is the house of Judah and the judges are the people themselves, howbeit, unknowingly to them. But in the final analysis, the plaintiff became the chief judge who meted out the punishment to the accused. Hence, the song can be situated within a continuum of the prophetic devices in which the prophet, through a parable, allows the hearers to convict themselves and unknowingly judge themselves. The parable is presented in such a way that the hearers look for the offenders outside of themselves. When Isaiah was using the vineyard metaphor in his song, the people might be thinking of the house of Israel, the Northern Kingdom because the vineyard metaphor was being used in relation to them by prophets before the time of Isaiah (cf. Hos 9:10; 10:1; 14:8; Ps 80). This device was also used by the prophet Nathan while trying to confront David with the sins of both adultery and murder in the parable he puts forward. Eventually David gave the punishment of what was to be done to the person who did wrong without knowing that he was the one (2 Sam 11 and 12). The exception to this device in Isa 5 is that while Nathan waited for the reaction of David before disclosing to him that he was the wicked rich man in the parable, Isaiah did not wait for the response or judgment of the people before declaring to them the true meaning of the parable, and that they are the unfruitful vineyard in question. In the opinion of Willis, the people might have pronounced judgment on themselves through some sort of agreement in their supposed silence between vv. 6 and $7 .^{25}$

The song can also be regarded as a relationship between husband and wife or between people that are bound together by covenant. It is to be noted that Yahweh's relationship with Israel has been portrayed by many prophets as that between husband and wife. For instance, Isaiah, like his northern contemporary Hosea, frequently uses the relationship of a groom and bride or husband and wife in speaking of the relationship between Yahweh and Israel (Isa 1:21; $3: 4 ; 27: 2-5$; Hos 10:1; Jer 2:21; Ps 80:9-17). ${ }^{26}$ It must be understood that there

23 Ivan D. Friesen, Isaiah (BCBC; Scottdale: Herald Press, 2009), 52.

24 John S. Kloppenborg Verbin, "Egyptian Viticultural Practices and the Citation of Isaiah 5:1-7 in Mark 12:1-9," Novum Testamentum 44/2 (2002): 137.

25 Willis, "The Genre," 347.

26 Willis, "The Genre," 348. 
has to be give and take in every relationship that will last, and all the parties involved must be ready to sacrifice their time, talents and resources as the occasion demands. In a situation where only one side or person is contributing to the common economy and to the sustenance of the relationship, sooner or later frustration may set in from the person contributing which, if not properly handled, may eventually lead to dislocation and disintegration of the relationship. If this happens, for the relationship to be restored, all the affected parties need to re-negotiate the terms and conditions of their mutual co-existence. In the song of the vineyard, Yahweh as the groom observed a strained relationship between him and the bride, the house of Judah, and decided to wield his authority by uttering a threat of judgment, if peradventure that will lead to the restoration of the relationship. It is equally observed that the period of breakdown in a relationship, no matter how brief, always brings with it moments of grief, destruction, despondency, economic lost and insecurity. This is denoted by the removal of the hedge around the vineyard for all kinds of stray animal to destroy the fruits in the garden.

\section{E IMPLICATIONS OF THE ISAIAH'S SONG OF THE VINEYARD FOR THE SOCIO-ECONOMIC AND SECURITY CHALLENGES IN NIGERIA}

Looking at the entity called Nigeria, one discovers that there are lots of similarities between and the house of Israel, the men of Judah and Nigeria. In the first instance, as the owner of the vineyard took it upon himself to plant his vineyard on a fertile soil and supply all that the vineyard would need for bountiful production and harvest without any effort from the vineyard, in the same manner, God has deposited many mineral resources into the Nigerian soil without her doing anything to deserve it. There is no gainsaying that God has blessed Nigeria with an abundance of both human and natural resources. Oshewolo, quoting Chukwuemeka, is of the opinion that the country is blessed with human and natural resources, but in the first four decades of its independence, the potentials remained largely untapped and even mismanaged. ${ }^{27}$ Nigeria is planted on a fruitful soil, and is blessed with good weather for agricultural production all the year round. Gold, precious stones of all kinds, iron and tourist centres, to mention just a few, are in large quantities for the development of the country. ${ }^{28}$

With the abundant provision of necessary resources for the developments that are enumerated above, one expects Nigeria to be one of the richest countries in the world and to be among the developing countries. However, Nigeria presents a paradox, whereby the level of poverty, infrastructural decay,

27 Segun Oshewolo, "Poverty Reduction and the Attainment of MDGS in Nigeria: Problems and Prospects," IJPGG 2/2.3 (2011): 2.

28 Isioma Aigbedion and Samuel E. Iyayi, "Environmental Effects of Mineral Exploitation in Nigeria," International Journal of Physical Sciences 2/2 (2007): 033. 
underdevelopment, unemployment, corruption, owing of workers' salaries in some States of the Federation for as much as seven months, ${ }^{29}$ etcetera, cannot be reconciled with the abundant resources available in the country. The rate of unemployment was so high to the extent that in 2014 over 200,000 applicants were pursuing only 4,500 available jobs in the Nigerian Immigration Service where about 16 of them met their untimely death arising from stampede and suffocation in many of the major cities where the written test held. ${ }^{30}$ Likewise, as a result of corruption which has grinded the refineries in Nigeria, crude oil that was given free of charge by God had to be exported for refining and be imported again for the Nigerian populace to buy at exorbitant prices. Initially the price of oil was subsidized by the Federal Government until 2012 when the said subsidy was removed by the President Goodluck Jonathan administration. This brought untold hardship on Nigeria and could be regarded as one of the most unpopular policies ever imposed on Nigerians. ${ }^{31}$ It could be regarded as a case of "a child of a meat seller eating bone." All these socio-economic vices can be likened to the wild or sour grapes that the owner of the vineyard in the Isaiah's song got during the time of the harvest, instead of good, tasty and abundant grapes. Just like the owner of the vineyard lamented the unexpected and poor yield of the vineyard, having given it all it needed for a bumper harvest, one also can raise the question, "what has gone wrong with Nigeria that it cannot make a head way in the comity of nations with all resources at its disposal"?

The answer to the above questions cannot be far-fetched because the social, economic, political and religious spheres of the country have been bedeviled by numerous social vices such as corruption in both public and private places, poverty, which has propelled widening class differences in the society, manipulation, distortion and perversion of justice in favour of the wealthy and to the detriment of the less privileged, to mention just a few. Unfortunately, the religious circles that are supposed to serve as an example of morality and champion the course of social justice are themselves enmeshed in all kinds of corruptions, ritual practices and all forms of social injustices. ${ }^{32}$ Coupled with the above is the issue of bad leadership or leadership failure, lack

29 Charles Kumolu, "Unpaid Salaries: Osun Judge Calls for Aregbesola Impeachment," Vanguard, 24 June (2015): 3.

30 Victoria Ojeme, et al., "Immigration Job Test Tragedy: Over 16 Feared Dead," Vanguard, 16 March (2014): 1. Cited 20 June 2015. Online: http://www.vanguardngr .com/2014/03.

31 Oluchi W. Nkwagu, "Fuel Subsidy Removal and the Nigerian Economy (A Case Study of Abakaliki Lical Government Area, Ebonyi State)," (B.Sc. Long Essay, Department of Public Administration, Caritas University, 2012), 11-13.

32 Samson O. Olanisebe, "The Prophetic Vocation of Amos in Amos 2:6-16 and its Relevance for National Development in Nigeria," AJBS 24/1 (2007): 29-30. 
of patriotism on the paths of both the leaders and the followers in Nigeria, $^{33}$ to mention just a few.

Having lamented the poor harvest from the vineyard, the owner decided to remove the hedge around it and allow it to be burned and become a trampling place that is not cultivated, but brings forth thorn bushes. These descriptions are expressions of the removal of protection devices so as to cause insecurity for the vineyard. It will become porous that stray animals and humans can access it and trample on it. To the houses of Israel and Judah, the description is a prophetic metaphor indicating their exposure to foreign invasion and the subsequent captivity through exile by those foreign and gentile nations, but to Nigeria, could it be the current insecurity problem that the country is facing? It is to be noted that since 2009, when the leader of Boko Haram (Muhammad Yusuf) was killed by the Police, the rate of insecurity has been on the increase. ${ }^{34}$ Before this time, the country has been bedevilled with insecurity problems that are concerned with resource based conflicts in the Niger Delta, ethno-religious conflict in Jos and communal clashes in some parts of the country. However, all these are child's play compared to the one posed by Boko Haram. Boko Haram has become a household name in Nigeria because of its indiscriminate killings of innocent people through bomb blasts, destruction of places of worship and important public places like markets and motor parks, abduction of women and girls, the recent and saddest being the abduction of over 200 secondary school girls in Chibok in Borno State, etcetera. As a matter of fact, some people have asserted that the number of people that have been killed by Boko Haram is more than those who died during the civil war in Nigeria. Emmanuel Oladosu has been quoted to have said that "since the end of civil war, no calamity of enormous proportion has befallen the fledging nation. Many lives have been lost, property worth billions of naira destroyed and the fact that nobody is insulated from the attack, for Government officials, traditional rulers, Police and Military formations and church worshippers are targets. There is panic on daily basis. The fear of the invincible agitator has become the beginning of wisdom. ${ }^{35}$ " This situation has produced wild grapes in Nigeria. When God and the people are looking for quality grapes of justice and righteousness, what Nigeria is producing is inferior quality grapes of bloodshed and cry. The demand for justice and righteousness by God from Nigerians has been met, most of the time and from majority of the populace, with injustice, violence, bloodshed, wickedness of all sorts, corruption, which has manifested in bribery, extortion, nepotism, tribalism, educational fraud such as admission

33 Samson O. Olanisebe and Abiola A. Olaniyi, "Nehemiah's Reform in Israel: A Challenge for Nation Building," Lumina 22/2 (2011): 155-156.

34 Ahmad Murtada, Boko Haram in Nigeria: Its Beginnings, Principles and Activities in Nigeria (Sokoto: SalafiManhaj, 2013), 1-8.

35 Olaide I. Aro, "Boko Haram Insurgency in Nigeria: Its Implication and Way Forwards Toward Avoidance of Future Insurgency," IJSRP 3/11 (2013): 1. 
fraud, examination mal-practices, certificate forgery, plagiarism, poor work ethics, dishonest in business, etcetera. ${ }^{36}$

One of the negative effects of this security challenge in Nigeria is the further drowning of the country in the ocean of underdevelopment. This is because security and development are interwoven. There cannot be any meaningful and sustainable development in an atmosphere of anarchy, insecurity, fear and panic. Nwanegbo and Odigbo, while giving conceptual explanations on the relationship between security and development, identify two lines of thoughts among scholars with regard to who should be the provider of security. The neo-realist believes that the sovereign state, to which the people have willingly submitted their rights to oversee the survival of all, should be saddled with the primary responsibility of providing effective security. The second line of thought, the postmodernist or pluralist displaces the state as the provider of security and places greater emphasis on non-state actors. To this group, human security and the economic security of the individual should be more paramount to the government and society than the security of the state. ${ }^{37}$ As a matter of fact, the rationale for the existence of the State is the protection of life and property within its territorial sovereignty, and in the case of Nigeria, this is clearly spelt out in the constitution. Therefore, the state will be deemed as having failed, to use the words of Arewa, "to the extent that it has failed to guarantee the safety of lives and property of its citizenry." ${ }^{, 38}$ Irrespective of the school of thought to which one belongs, the truth is that security is the collective responsibility of both the state and the individual entities therein, though the state should be held responsible if anything goes wrong.

The question this paper raises is, just as the owner of the vineyard asked in Isaiah's song, what more should have been done by God for Nigeria that has not been done? What resources are Nigeria lacking that has warranted the sorry and gory state it has found itself in? Whose fault is the bane of Nigeria's misery and underdevelopment, is it God, or the political leaders or the ordinary people? The fact is that God has no share in the socio-economic and security challenges of Nigeria. He has done what needs to be done for a country to develop. He has given the necessary resources in abundance and many of those resources are yet to be exploited. However, the problem is the ruling class who has not distributed the resources fairly and equitably, thereby allowing an infinitesimal number of people to be in control of the state resources. The

36 Adrain A. Helleman, "Ten New Biblical Commandments for Fighting Corruption in Africa," in Biblical Studies and Corruption in Africa (ed. Samuel O. Abogunrin, et al.; BS 6; Ibadan: National Association for Biblical Studies (NABIS), 2007), 3.

37 C. Jaja Nwanegbo and Jude Odigbo, "Security and National Development in Nigeria: The Threat of Boko Haram," IJHSS 3/4 (2013): 286.

38 John A. Arewa, "Core National Values as Determinant of National Security and Panacea for the Crime of Kidnapping and Abduction in Nigeria," n.p. [cited 12 July 2014]. Online: www.nials-nigeria.org/pub/JohnAdebisiArewa.pdf. 
political leaders are to be held responsible because they are people that have been elected, co-opted or appointed to be in control of the state resources with the belief that they are going to protect the interest of all irrespective of ethnic or religious divides. But the opposite has been the case in Nigeria. With impunity there is embezzlement of public funds by these leaders and their allies. How would one explain the contract of the installation of CCTV cameras in the metropolis of Abuja where many did not work and nothing is done to the contractor? Is it the fault of God or leadership failure in Nigeria? If God then decides to allow the country to face the music of its wastefulness, corruption and mal-administration with the ripple effects of poverty, insecurity and underdevelopment, is God unjust? The answer to the question is in the negative.

\section{F CONCLUSION}

What has been demonstrated in this paper is the lasting relevance of the messages of Israel's prophets without recourse to differing cultural contexts and distance in time and space. The view of some scholars is that the OT prophets are people of their time and that their messages are to the people of their time and not to later generations. While this statement is partially correct about the messages of the OT prophets, it is equally a fact that the relevance of their messages to the 21 st century people and nations cannot be over-emphasised. This is because even though the prophets were sent to the nation of Israel, the latter is only a means to an end, embedded in their messages is the universality of Yahweh. It is not surprising, therefore, if reading through Isaiah's song of the vineyard, one discovers a similar situation of resources wastage, resources mismanagement, dashed hopes and expectations that have launched the country into the state of economic woes, underdevelopment and insecurity. However, as the prophetic messages always serve as warning signals to the affected individuals and nations and calling for their repentance and return to Yahweh, there is hope for Nigeria also to rise again, if it can look inward and identify the areas

of failure in the process of nation building and correct such failures with a strong determination to succeed.

\section{BIBLIOGRAPHY}

Aigbedion, Isioma and Samuel E. Iyayi, "Environmental Effects of Mineral Exploitation in Nigeria." International Journal of Physical Sciences 2/2 (2007): 033-038.

Anderson, George W. A Critical Introduction to the Old Testament. London: Gerald Duckworth \& Co. Ltd., 1974.

Arewa, John A. "Core National Values as Determinant of National Security and Panacea for the Crime of Kidnapping and Abduction in Nigeria." No pages. Cited 12 July 2014. Online: www.nials-nigeria.org/pub/JohnAdebisiArewa.pdf.

Aro, Olaide I. "Boko Haram Insurgency in Nigeria: Its Implication and Way Forwards Toward Avoidance of Future Insurgency." International Journal of Scientific and Research Publications 3/11 (2013): 1-8.

Bright, John. A History of Israel. 3rd ed. London: SCM Press, 1982. 
Chaney Marvin L. "Whose Sour Grapes? The Addressees of Isaiah 5:1-7 in the Light of Political Economy," Semeia 87 (1999): 105-122.

Constable, Thomas L. "Notes on Isaiah." 2015 Edition. 246 pages. Cited 22 June 2015. Online: http://soniclight.com/constable/notes/pdf/isaiah.pdf.

Evans, Craig A. "On the Unity and Parallel Structure of Isaiah." Vetus Testamentum 38/2 (1988): 129-147.

Friesen, Ivan D. Isaiah. Believers Church Bible Commentary. Scottdale: Herald Press, 2009.

Graham, William C. "Notes on the Interpretation of Isaiah 5:1-14." The American Journal of Semitic Languages and Literatures 45/3 (1929): 167-178.

Helleman, Adrian. A. "Ten New Biblical Commandments for Fighting Corruption in Africa." Pages 12-33 in Biblical Studies and Corruption in Africa Edited by Samuel O. Abogunrin, James O. Akao, Dorcas O. Akintunde, Adekunle O. Dada, Godwin N. Toryough and Paul A. Oguntoye. Biblical Studies 6. Ibadan: National Association for Biblical Studies (NABIS), 2007.

House, Paul R. "Isaiah's Call and Its Context in Isaiah 1-6." Criswell Theological Review 6/2 (1993): 201-222.

Keung, Kwok Chi. "An Analysis of the 2 Vineyard Songs in Isaiah." Graduation Thesis, Hong Kong Catholic Biblical Institute, 2007.

Kloppenborg Verbin, John S. "Egyptian Viticultural Practices and the Citation of Isaiah 5:1-7 in Mark 12:1-9." Novum Testamentum 44/2 (2002): 134-159.

Kumolu, Charles. "Unpaid Salaries: Osun Judge Calls for Aregbesola Impeachment." Vanguard, 24 June (2015): 3

Moberly, R. Walter L. "Whose Justice? Whose Righteousness? The Interpretation of Isaiah V 16." Vetus Testamentum 51/1 (2001): 55- 68.

Motyer, J. Alec. The Prophecy of Isaiah: An Introduction and Commentary. Downers Grove: Inter Varsity Press, 1993.

Murtada, Ahmad. Boko Haram in Nigeria: Its Beginnings, Principles and Activities in Nigeria. Sokoto: SalafiManhaj, 2013.

Nwanegbo, C. Jaja and Jude Odigbo. "Security and National Development in Nigeria: The Threat of Boko Haram." International Journal of Humanities and Social Science 3/4 (2013): 285-291.

Nkwagu, Oluchi W. "Fuel Subsidy Removal and the Nigerian Economy (A Case Study of Abakaliki Lical Government Area, Ebonyi State).” B.Sc. Long Essay, Department of Public Administration, Caritas University, 2012.

Ojeme, Victoria, et al. "Immigration Job TestTragedy: Over 16 Feared Dead." Vanguard, 16 March (2014): 1. Cited 20 June 2015. Online: http://www .vanguardngr.com/2014/03.

Olanisebe, Samson O. "The Prophetic Vocation of Amos in Amos 2:6-16 and Its Relevance for National Development in Nigeria." African Journal for Biblical Studies 24/1 (2007): 19- 38.

Olanisebe, Samson O. and Abiola A. Olaniyi. "Nehemiah's Reform in Israel: A Challenge for Nation Building." Lumina: A Refereed Interdisciplinary Research and Scholarly Journal of Holy Name University 22/2 (2011): 147-161.

Oshewolo, Segun. "Poverty Reduction and the Attainment of MDGS in Nigeria: Problems and Prospects." International Journal of Politics and Good Governance 2/2.3 (2011): 1-22. 
496 Olanisebe, "The Justice of God," OTE 28/2 (2015): 481-496

Sheppard, Gerald T. "The Anti-Assyrian Redaction and the Canonical Context of Isaiah 1-39." Journal of Biblical Literature 104/2 (1985):193-216.

Whitley, Charles F. "The Call and Mission of Isaiah." The Journal of Near Eastern Studies 18/1 (1959): 38-48.

Williams, Gary R. "Frustrated Expectations in Isaiah V 1-7: A Literary Interpretation." Vetus Testamentum 35/4 (1985): 459-465.

Willis, John T. “The Genre of Isaiah 5: 1-7.” Journal of Biblical Literature 96/3 (1977): 337-362.

Webb, Barry. The Message of Isaiah. Leicester: Inter-Varsity Press, 1996.

Dr Samson Olusina Olanisebe, Department of Religious Studies, Obafemi Awolowo University, Ile-Ife, Nigeria. Email: soolanisebe@yahoo.com. 